\title{
International entrepreneurship in universities: Context, emergence and actors
}

\author{
Natasha Evers ${ }^{1,2}$ • James A. Cunningham ${ }^{3}$. \\ Thomas Hoholm ${ }^{4}$
}

Published online: 14 July 2016

(C) Springer Science+Business Media New York 2016

\begin{abstract}
This special issue presents an opportunity to explore the international aspects of academic and university based international entrepreneurship. Over the last decades much research attention has been focused on university spin-off firms (USOs) on issues such as, creation, risk, strategies and performance (see Druilhe and Garnsey, 2004; Link and Scott, 2005; Lockett and Wright, 2005; Walter et al, 2006; Wright et al., 2006). There has been a dearth of studies that have examined the international dimensions and aspects of university-based spin-off firms. The six articles presented in this special issue point towards interesting future research agendas at the interface between academic and international entrepreneurship. Three core themes emerge from this special issue: Context, Emergence and Actors. In sum, this special issue pinpoints: firstly, specific features of universities and research organizations as contexts for international technology entrepreneurship; secondly, the process of organizational emergence and entrepreneurial cognition; and thirdly, insight into learning processes of USOs and the role of non-academic actors. Our article concludes by identifying future avenues of
\end{abstract}

Natasha Evers

Natasha.evers@nuigalway.ie

James A. Cunningham

james.cunningham@northumbria.ac.uk

Thomas Hoholm

Thomas.hoholm@bi.no

1 Marketing Discipline, J.E. Cairnes School of Business \& Economics, National University of Ireland, Galway, Ireland

2 Centre for Innovation, Entrepreneurship and Learning (CIEL), Halmstad University, Halmstad, Sweden

3 Newcastle Business School, Northumbria University, Newcastle Upon Tyne, UK

4 Department of Innovation and Economic Organisation, BI Norwegian Business School, Oslo, Norway 
research.Résumé Ce numéro spécial représente une occasion rare d'explorer les aspects internationaux de l'entrepreneuriat international fondé académique et universitaire. Au cours des dernières décennies, une attention beaucoup de recherche a été mise sur l'université des entreprises spin-off sur des questions telles que la création, le risque, les stratégies, les performances (voir Druilhe et Garnsey, 2004; Link et Scott, 2005; Lockett et Wright, 2005; Walter et al. 2006; Wright et al, 2006). Il y a eu un manque d'études qui ont examiné les dimensions et les aspects de l'université sur la base des entreprises spin-off internationaux. Les six articles représentés dans ce point de numéro spécial vers les futurs programmes intéressants de recherche dans l'interface entre l'entrepreneuriat universitaire et international. De la collection de numéro spécial trois thèmes principaux émergent: Contexte, Émergence et Acteurs. En somme, cet article souligne, premièrement, les caractéristiques spécifiques des universités et des organismes de recherche comme des contextes pour l'esprit d'entreprise technologique internationale. Deuxièmement, il souligne le processus d'émergence organisationnelle et de la cognition entrepreneuriale, et, troisièmement, la compréhension des processus d'apprentissage des entreprenariats technologiques universitaires et le rôle des non acteurs - académiques. Nous concluons en identifiant les voies futures de recherche à la fin de l'article

Keywords academic entrepreneurship - international entrepreneurship · university spinoffs · networks · technology entrepreneurship · innovation · clusters · internationalization · commercialization

Mots-clés entrepreneuriat international - entreprenariats universitaires · Academic entrepreneurship

\section{Introduction}

The past two decades have witnessed a dramatic increase in investment in technology entrepreneurship in universities and public research organizations (Evers et al., 2014; Wright et al., 2006). Technology entrepreneurship can be defined as 'an investment in a project that assembles and deploys specialized individuals and heterogeneous assets that are intricately related to advances in scientific and technological knowledge for the purpose of creating and capturing value for a firm' (Bailetti, 2012, p. 5). Universities are now seen as key actors in driving economic growth particularly in knowledge-based economies (Feller, 1990; Mowery, 2004). Technology transfer and a drive towards commercialization and exploitation of technological innovations in higher education institutions (HEIs) and public research organizations (PROs) have been brought to the forefront of the innovation and economic agenda in most developed economies (Evers et al., 2014; Cunningham and Link, 2015; Cunningham and Link, 2016). As part of their technology and knowledge transfer strategies, universities have increasingly supported spin-out ${ }^{1}$ and spin-in firms and this has created challenges for both universities and founders of university-based spin-off firms (see and Pirnay et al. 2003). Moreover, universities are now focusing on approaches and mechanisms that will enhance and add further value to university-based spin-offs (see Schiavone et al., 2014; Mian 1996). The creation of university incubators has been an institutional response of many universities 
to a growing demand from policy makers and funding agencies to the need for commercialization of research and creation of university-based spins-offs. Incubators enable universities to engage and mobilize internal and external networks supporting the creation of viable and sustainable university start-up firms (McAdam et al., 2006; McAdam and McAdam, 2008; Guerrero et al., 2014; Hisrich and Smilor, 1988). University incubators have put in place formal and informal supports for incubated firms to support their growth and development such as networking, programmes etc. (Bergek and Norrman, 2008; Gately and Cunningham, 2014; McAdam and Marlow, 2008; Rothaermel and Thursby 2005). Moreover, scientists are seen as key actors in market shaping of university and are more influential actors in determining the direction of technology transfer and research commercialization (see Mangematin et al., 2014; Menter, 2016; O'Kane et al., 2015). Such increased levels of activities have led to the growth of spin-off firms. Most spin-offs that emerge from research environments are typically technologically driven, and their expansion into foreign markets has become a commercial priority to generate revenues and thus to recuperate the initial R\&D and patent costs over a shorter time frame (Evers et al., 2012).

Internationalization of firms is challenging, and there can be further complexity for university-based spin-offs. Not alone do they have to deal with the international challenges experienced by firms but also have to deal with institutional-based constraints and barriers that may prevent them from realizing international ambitions such as a lack of technology transfer support (Cunningham et al., 2014). From the articles in this special issue, we observe in line with previous research (Andersson et al., 2013) that the higher the knowledge-intensity of the sector, the greater is the reliance on local research infrastructures - i.e. universities, hospitals, research institutions for internationalizing innovations through the creation and development of international new ventures (INVs). Hence, the emergence of university spin-off firms (USOs)-INVs in primarily high-technology sectors aligns well with mainstream typically high-tech orientated INV/born global ventures. It has been recognized that both innovation and new venture internationalization are deeply connected, with entrepreneurship embracing the two (Zucchella and Siano, 2014; Keen and Etemad, 2012).

University spin-offs are described as 'new firms created to exploit commercially some knowledge, technology or research results developed within a university' (Pirnay, Surlemont and Nlemvo, 2003). For many high-technology ventures in this context, internationalization has increasingly become a growth strategy to enable the pursuit of larger markets and exploitation of new innovations to full fruition (Keen and Etemad, 2012; Teixeira et al., 2014; Evers et al. 2014). However, technological superiority is not a guarantee for high-technology firms' success. In fact, companies find it exceedingly more difficult to gain international competitive advantage on the basis of state-of-theart technology alone. High-technology firms will not prosper solely on the basis of outstanding R\&D activities; they need to be complemented with marketing and market development strategies and activities that successfully take the innovation into the international market place (Evers, et al., 2014). The manner in which new ventures choose to commercialize, market and internationalize themselves is critical to their survival, especially when exposed to competition, greater complexity, dynamism and uncertainty (Evers, et al., 2012).

The focus of this Special Issue (SI), therefore, is on international entrepreneurship in the context of Higher Education Institutions (HEIs) and Public Research Organisations 
(PROs). In particular, we invited conceptual and empirical papers from different domains that addressed interactions and activities of internationalization of such new ventures based in HEI contexts. Interaction oriented perspectives have long been influential in IE research (see Etemad 2004a,b; Evers, 2010; Johanson \& Mattsson, 1986; Johanson \& Vahlne, 2003;), as well as in technology entrepreneurship (e.g. Garud and Karnoe, 2003; 2001; Ciabuschi et al., 2012; Strömsten and Waluszewski, 2012) and innovation management (e.g. Van de Ven et al., 1999; Håkansson \& Waluszewski, 2007; Hoholm \& Olsen, 2012). We argue that there is more to gain in studying international interactions and activities in international entrepreneurship in the university context. Further understanding is required related to the embedding of resources in foreign business networks, knowledge diffusion through institutional interactions, mutual learning, and path creation. This is relevant now as a recent UK study measuring the economic impact of UK universities highlights that the greatest economic role for more research-intensive universities (Russell Group) is to deliver university spin-off firms (Guerrero et al., 2015). Therefore, university-based technology entrepreneurship needs to be better understood in terms of how new technology ventures are altered during international interactions, the role of power relations and ownership, the alignment of actors and the negotiation of stakeholder roles during internationalization processes.

\section{Contexts, emergence and actors}

\section{Universities as contexts for international entrepreneurship}

There is a relative lack of connections between the literatures on international entrepreneurship and university-based entrepreneurship. In academia, scientists typically work and are identified as participants in highly international networks, such as 'epistemic cultures' (Knorr-Cetina, 1999) and 'networks of practice' (Amin \& Roberts, 2008). Hence, technology research in HEIs and PROs is increasingly international in nature. Knowledge resources are widely shared and mobilized across organisational and national borders (Andersson, Evers and Grigot, 2013). Personal expertise is on routine basis demonstrated through joint projects and publications. Research instruments of various sorts are increasingly the outcome of joint international endeavors (e.g., CERN-The European Centre of Nuclear Research, is a powerful example), and national contexts have therefore become less important for accounting for knowledge flows in science as well as in industry.

On the other hand, while the transfer and utilization of academic knowledge can be desirable for economic and/or social gains, it is not obvious that academic research settings are particularly beneficial settings for nurturing commercialization and industrialization - e.g. through spin-offs and new venture creation. Similarly, internal university practices, institutional logics, and incentive structures may not be well aligned, and the experience with and network connections to industry may be weak. In this special issue, Andersson and Berggren's article, 'Born Global or Local? Factors influencing the Internationalization of University Spin-Offs-The Case of Halmstad University', addresses these issues with a qualitative analysis of 10 university-based spin-offs (USOs) based in Halmstad University. They find that USOs are typically born 
global firms (BG) and that the regional technology university, in which the spin-offs were embedded, are instrumental in facilitating more international entrepreneurship in a South West region of Sweden. However, they point out that BG business models are not necessarily by themselves helpful for producing growth. Growth, they argue, rather seems to emerge from the venture's active engagement with internationally connected customers and not only systematically adapting their offerings to customer needs.

Staying with firm growth, in the next article of this Issue: 'Growth Determinants of Entrepreneurship: A longitudinal study of Spanish Technology University Spin-offs', Rodriguez-Guilas et al. present their findings from a longitudinal study of growth patterns of 340 Spanish university founded and non-university founded technology based firms (TBFs). Rodriguez-Guilas et al. show that there is a strong correlation between new venture growth and academic founding in a university context. This study finds that TBFs with university origins that are locally connected to the region through the university are more likely to grow successfully than those TBFs that have no academic roots. Rodriguez-Guilas et al. suggest that HEIs and PROs may indeed act as fertile ground for entrepreneurial activities and that an USO, at least in some national/ institutional contexts, may be an effective mechanism for technology transfer from universities. However, more fine-grained analysis is needed to fully understand the mechanisms and contextual factors impacting on USOs' growth and internationalization.

\section{Organisational emergence and entrepreneurial cognition}

There have been multiple calls for more process-oriented studies of entrepreneurial and innovation journeys, because of the need to understand how opportunities are recognized, resources are mobilized, entrepreneurs learn effectively, networks influences realized and success achieved, among other questions. In general, this has gradually become central to entrepreneurship research, with seminal contributions like McGrath \& MacMillan (1995) on discovery driven planning, Garud \& Karnøe (2001) on entrepreneurial path creation, and Sarasvathy (2001) on expert entrepreneurs' effectuation logic. Such themes of organisational emergence and entrepreneurial cognition need to be examined in the context of university-based entrepreneurship. We highlight two articles in this Special Issue, by Hannibal et al. and the other article by Stayton and Mangematin, which initiate this process of inquiry. Both articles examine USOs in different country and high-technology industry contexts to explore specifically how these ventures emerge and the activities enacted by their founding academic entrepreneurs and teams. Firstly, the article in this Issue by Hannibal, Evers and Servais, titled: 'Opportunity and International New Venture Creation in University Spin-offs: Cases from Denmark and Ireland', explores how university-based inventor-founders in Denmark and Ireland recognize opportunities whilst researching in their fields of science and engineering. The authors (Hannibal et al., in this Issue) combine theories of effectuation, organisational emergence and self-efficacy to contribute to the IE knowledge by examining the processes of how USOs are formed to exploit these opportunities by developing products and services for international markets. Hannibal et al. (this Issue) also place emphasis on action and resources for recognizing opportunities and speeding up the commercialization process. Similarly, the authors (Hannibal et al. in this Issue) discover that the activities and processes of developing 
USOs resemble those we know from the literature on international new ventures (INVs). Building and using a founder-centric analytical framework, Hannibal et al. (in this Issue) argue that academic entrepreneurs can typically engage creatively with opportunity recognition, and also, the resourcing and organizing the USO processes largely happen through the inventor-founder's cognitive tendencies towards 'selfefficacy' and effectuated decision-making for international new venture creation.

Moving beyond the nascent entrepreneurial process, the next article in this Issue, by Stayton and Mangematin's article, 'Startup time: Compressing simultaneous innovation and organizational emergence in international university technology ventures', deliver an interesting longitudinal comparative cases of US-based clean-technology start-ups. Focusing on the launch-time of the start-up process, Stayton and Mangematin (in this Issue) highlight the importance of speed: how the simultaneous development of the new product and the new organisation may significantly influence the success of the entrepreneurial processes. The authors argue that 'time' can be seen as a resource in itself and needs to be managed carefully in this phase when innovation and venture formation are concurrent. Hence, Stayton and Mangematin's article (in this Issue) contributes to the field by highlighting the challenges of speeding up the process of venture creation through managing a co-existing set of tensions between temporal, financial and human resources.

\section{Learning and resourcing: The role of academic and non-academic actors}

How entrepreneurs learn and appropriate resources has been of interest to researchers (see Cope \& Watths, 2000: Harrison and Leitch, 2005; Minnit and Bygrave, 2001; Politis, 2005). In various strands of the international entrepreneurship literature, the need for firm learning is mobilized through network (Johanson \& Vahlne, 2003; Johanson \& Mattsson, 1986; Oviatt \& McDougall, 2005). In this way, the learning problem may be shortcut by involving actors with various kinds of experience and expertise, as well as physical and monetary resources. The challenge of speed (Stayton \& Mangematin's article in this Issue), the liabilities of newness and foreignness (Zaheer, 1995) as well as the unpredictability of interactions (Hoholm \& Olsen, 2012) point to the need for systematic and often rapid learning of entrepreneurs and entrepreneurial teams in the face of high uncertainty. We highlight two articles in this Special Issue, by Franco-Leal, Soetanto and Camelo-Ordaz and the other article by Mikhailova and Olsen that have a specific focus on the USO learning through the role of non-academics and the learning of university-based international entrepreneurial ventures. Both articles are related to the fundamental problem of learning during entrepreneurship processes.

In their article, 'Do they matter? The role of non-academics in the internationalization of university spin-offs', Franco-Leal et al. (in this Issue) investigate the role of nonacademics for performance and internationalization of academic spin-offs, by analyzing 126 Spanish domestic and international academic spin-offs. Franco-Leal et al. find that non-academics in the founder team, as well as in the new venture's network, had positive effects on internationalization, performance and partially also on the venture's ability to innovative.

A striking example of how actors with different kinds of experience, expertise and resources may influence the process is shown in this Special Issue in the article titled 
'Internationalization of an academic invention through successive science-business networks: The Case of TAVI'. In this article, Mikhailova and Olsen conduct a longitudinal case study on the development and internationalization of an academic invention turned-advanced medical technology demanded by global markets. Complementing the inventor-founder and the entrepreneurial team perspectives of three of the articles in this Special Issue by Hannibal, Evers and Servais; Stayton and Mangematin; and Mikhailova and Olsen, describe how a new technology venture may be pulled through subsequent phases by academic and business actors, can alter the international trajectory and pathways of the medical technology venture. Mikhailova and Olsen's study in this Special Issue follows how the venture leverages the knowledge and expertise of business actors by moving in and taking control. Mikhailova and Olsen's article (in this Issue) identified R\&D organisations, venture capital firms and established industrial companies to possess the required experience and the resources needed at the time by the academic founded venture. The author's article (Mikhailova and Olsen) finds that the case venture's science and business networks were important in enabling it to move its technology and the new venture itself through a certain set of challenges, before new actors may move in to manage the next phases. With this, Mikhailova and Olsen's article contributes by highlighting the mechanisms through which non-founder experience, venture capitalists and science (academic) networks can influence the trajectory of an academic invention and its transformation into the highly commercialized and scalable global technology venture.

\section{Concluding remarks}

We want to firstly express our thanks to JIEN Editor-in-Chief, Professor Hamid Etemad for inviting us to guest edit this Special Issue on this important area of academic entrepreneurship and university-based international entrepreneurship. We also thank sincerely the reviewers of this issue. This JIEN special issue has been the first of its kind to call for examining these types of ventures in the context of international entrepreneurship. This issue highlights the critical role that universities and research institutes play in the development and creation of innovation-driven INVs. This area of research is still in its infancy, and there is a need for more research combines that INV and IE fields. In doing so, we offer a number of emergent research themes to guide future research in this important area of IE research.

Firstly, the issue brings forth the importance of university context as a melting pot for scientific discoveries that can be commercialized into a business and more over an international one. The local presence of research institutions can influence academic spin-off's capacity to leverage innovation networks for its internationalization process. Similarly, for international growth, academic entrepreneurs and non-academic founders in universities can leverage and mobilize international scientific and university networks to endorse and promote their products internationally. Similarly, Audretsch and Stephan (1996) found that entrepreneurs tend to create contacts with scientists working in the same geographical area, particularly if the scientists are active in firm creation. In line with INV research, we note that the greater the knowledge intensity of the industry, the greater is the reliance on local research infrastructures for internationalizing innovations emanating from regional industry clusters (Andersson et al. 2013). For example, close co-operation with university hospitals has been found 
to be especially important in the medical technology and health science sectors (Weigel, 2011) and for facilitating international growth of the medicine-technology small firms. Therefore, we suggest that further research is required into how universities, research institutions and hospitals can serve as hubs for knowledge diffusion and product development processes through which innovation can be commercialized and internationalized. Further investigation is needed into ways such academic research infrastructures can facilitate international entrepreneurship activities and the propensity for the emergence of INVs in such contexts.

Second, we note that key factors influencing university interactions across different countries is very much policy driven by motivating researchers and scientists to work and collaborate together on innovation to attract European and Regional funding (i.e. Horizon 2020; INTERREG). In the last decade, we have witnessed a high degree of internationalization of university $\mathrm{R} \& \mathrm{D}$ collaborations with a strong commercial remit in terms of their outputs. Such R\&D project can pool international teams of expertise and lead to scientific discoveries with a strong commercialization potential. As result, national government research policies at European and international levels through cross country collaborative research projects have generated greater international connectivity and knowledge diffusion across local academic institutions and industry. Evidence has shown that university links to national and international industry are often much stronger than links to local industry (Cooke and Huggins, 2003).

Third is the role of actors within local entrepreneurial eco-systems in supporting the internationalization of USOs. This special issue has highlighted the role of nonacademic actors and this further empirical investigation. For example, does the individual international orientation of actors influence founders and founding teams as they develop and grow their USOs? Does the international orientation of transfer technology office (TTO) Directors and TTO professionals really influence the international orientation of USOs? If so, in what ways and what are the most effective engagement mechanisms by actors with founding USO teams. Moreover, what supports can actors use to stimulate internationalization of USOs and how do (or should) they differ for USOs who do not have born global or international ambitions or orientations? Addressing and integrating these issues to the growing entrepreneurship eco-system and principal investigator literature would contribute to better understanding the impact and influence of individual actors on the internationalization of USOs (see Audretsch and Belitski, 2016; Cunningham et al., 2016b; Stam, 2015).

Fourth, further research is warranted on resourcing and opportunity recognition of founding USOs teams that are seeking to internationalize from foundation and particularly USOs that are seeking to exploit digital and circular economy platforms. How do internationally orientated USOs effectuate their local, national and global networks to secure resources effectively to scale and build internationally orientated business models? Moreover, what market validation processes and activities do they use to validate their international orientation? What marketing development strategies and activities do these USOs adopted in order to create an international competitive advantage? Future research could build on marketing development strategy and commercialization of new ventures to address some of these issues (see Evers et al., 2014: Evers et al., 2012).

Fifth, the empirical evidence from the papers in the special issues suggests that internationally oriented USOs face specific, significant and unique challenges (Evers 
et al., 2012). Many of these USOs do not survive the challenges they face in scaling internationally effectively. What are the causes of failure of internationally orientated USOs? Have failed founders of internationally orientated USOs been able to recover from failure and how has fear, grief and stigmatization influenced their professional lives and future decisions that they have undertaken? Drawing together IE, USO literatures and the growing literature on business failure would significantly advance our knowledge and offer some relevant insights to founders, universities and actors to mitigate and reduce failure rates of internationally orientated USOs (see Byrne and Shepard, 2015; Ucbasaran et al. 2013; Walsh and Cunningham 2016).

Finally, in advancing this under researched area in IE, there is a need for researchers to embrace different methodological approaches and use different data collection methods. Significant contributions can be made to advancing this domain through cross-country studies as well as single case studies or national studies. There is an urgency in advancing this domain given the changing nature of the exploitation and commercialization of university-based research, increasing levels of international academic research collaborations and the globalization of markets and consumers.

\section{Note}

1. Spin-out refers to ventures created as a result of technologies or knowledge transferred from existing organisations to an already existing firm. A spin-out could for example include academic research that is transferred to and commercialized in an already existing firm. Spin-ins are companies started up with seed money from an existing organisation and then acquired by the latter. However, spin-off is usually connected with the start-up of a new firm. However, the term spin-outs and spin-offs have been used interchangeably in the literature and in industry circles. We use the term 'Spin-off' in this article to define academic knowledge created in existing organisation (the university) used to create an entirely new venture (Pirnay et al., 2003).

\section{References}

Amin A, Roberts J (2008) Knowing in action: beyond communities of practice. Res Policy 37(2):353-369

Andersson S, Evers N, Grigot C (2013) Local and international networks in small firm internationalization: cases from the Rhone-Alpes medical technology regional cluster. Entrepreneurship And Regional Development 25:867-888

Audretsch DB, Belitski M (2016) Entrepreneurial ecosystems in cities: establishing the framework conditions. J Technol Transf:1-22

Audretsch DB, Stephan PI (1996) “Company-scientist locational links: the case of biotechnology. Am Econ Rev 86(3):641-652

Teixeira A, Coimbra C (2014) The determinants of the internationalization speed of Portuguese university spin-offs: an empirical investigation, Journal of international Entrepreneurship, Fall 2014, V12, No. 3.

Bailetti, T. (2012). Technology Entrepreneurship: Definition, Overview and Distinctive Aspects. Technology Innovation Management Review, February 2012. 5-12.

Bergek A, Norrman C (2008) Incubator best practice: a framework. Technovation 28(1):20-28 
Byrne O, Shepherd DA (2015) Different strokes for different folks: entrepreneurial narratives of emotion, cognition, and making sense of business failure. Entrepreneurship Theory and Practice 39(2):375-405

Ciabuschi F, Perna A, Snehota I (2012) Assembling resources when forming a new business. J Bus Res 65(2): 220-229

Cetina KK (1999) Epistemic cultures: how the sciences make knowledge. Harvard University Press

Cooke P, Huggins R (2003) High technology clustering in Cambridge. In: Amin A, Goglio S, Sforzi F (eds) The institutions of local development. IGU, London, pp. 51-74

Cope J, Watts G (2000) Learning by doing - an exploration of experience, critical incidents and reflection in entrepreneurial learning. International Journal of Entrepreneurial Behavior \& Research 6(3):104-124

Cunningham J, O'Reilly P, O'Kane C, Mangematin V (2014) The Inhibiting Factors that Publicly Funded Principal Investigators Experience in Leading Publicly Funded Research Projects. Journal Of Technology Transfer 39(1):93-110

Cunningham JA, Link AN (2015) Fostering University-Industry R\&D Collaborations in European Union Countries. Int Entrep Manag J 11(4):849-860

Cunningham JA, Link AN (2016) Exploring the effectiveness of research and innovation policies among European Union countries. Int Entrep Manag J 12(2):415-425

Cunningham, O'Reilly JA, C O'Kane P, Mangematin V (2016b) Publicly Funded Principal Investigators as Transformative Agents of Public Sector Entrepreneurship in David Audretsch and Al Link, essay in public sector entrepreneurship. Springer, pp. 67-93

Druilhe C, Garnsey E (2004) Do academic spin-outs differ and does it matter? J Technol Transf 29(3-4):269285

Evers N (2010) Factors influencing the internationalisation of new ventures in the Irish aquaculture industry: an exploratory study. J Int Entrep 8(4):392-416

Evers, N., Cunningham, J. and T. Hoholm (2014). Technology Entrepreneurship - Bringing Innovation to the Marketplace. Palgrave-Macmillian. London, UK.

Evers N, Andersson S, Hannibal M (2012) Stakeholders and marketing capabilities in international new ventures: evidence from Ireland, Sweden and Denmarks. J Int Mark 20(4):46-71

Etemad H (2004a) International entrepreneurship as a dynamic adaptive system: towards a grounded theory. J Int Entrep 2(1 and 2):5-59Spring 2004

Etemad H (2004b) Internationalization of small and medium-sized enterprises: a grounded theoretical framework and an overview. Canadian Journal of Administrative Sciences 21(1):1-21Spring 2004

Feller I (1990) Universities as engines of R\&D-based economic growth: they think they can. Res Policy 19(4): 335-348

Garud, R., \& Karnøe, P. (2001). Path dependence and creation. Lawrence ErlbaumAssociates.

Garud R, Karnøe P (2003) Bricolage versus breakthrough: distributed and embedded agency in technology entrepreneurship. Res Policy 32(2):277-300

Gately C, Cunningham JA (2014) Building intellectual capital in incubated technology firms. J Intellect Cap 15(4):516-536

Guerrero M, Urbano D, Cunningham J, Organ D (2014) Entrepreneurial universities in two European regions: a case study comparison. J Technol Transfer 39(3):415-434

Guerrero M, Cunningham J, Urbano D (2015) Economic impact of entrepreneurial universities' activities: an exploratory study of the United Kingdom. Res Policy 44(3):748-764

Håkansson, H., \& Waluszewski, A. (Eds.). (2007). Knowledge and innovation in business and industry: The importance of using others. Routledge.

Harrison RT, Leitch CM (2005) Entrepreneurial learning: researching the interface between learning and the entrepreneurial context. Entrepreneurship Theory and Practice 29(4):351-371

Hisrich RD, Smilor RW (1988) The university and business incubation: technology transfer through entrepreneurial development. J Technol Transf 13(1):1419

Hoholm T, Olsen PI (2012) The contrary forces of innovation: a conceptual model for studying networked innovation processes. Ind Mark Manag 41(2):344-356

Johanson J, Mattsson LG (1986) International marketing and internationalization processes: a network approach. In: Turnbull PW, Paliwoda S (eds) Research in international marketing. Routledge, Abingdon, pp. 234-265

Johanson J, Vahlne JE (2003) Business relationship learning and commitment in the internationalization process. J Int Entrep 1(1):83-101

Keen C., and Etemad H (2012) Rapid growth and rapid internationalization: the case of Smaller Enterprises from Canada Management decision 50:569-590

Lockett A, Wright M (2005) Resources, capabilities, risk capital and the creation of university spin-out companies. Res Policy 34(7):1043-1057 
Link AN, Scott JT (2005) Opening the ivory tower's door: an analysis of the determinants of the formation of US university spin-off companies. Res Policy 34(7):1106-1112

Mangematin V, O'Reilly P, Cunningham J (2014) PIs as boundary spanners, science and market shapers. J Technol Transfer 39(1):1-10

Menter M (2016) Principal investigators and the commercialization of knowledge. In: In University Evolution, Entrepreneurial Activity and Regional Competitiveness. Springer International Publishing, pp. 193-203

Mian SA (1996) Assessing value-added contributions of university technology business incubators to tenant firms. Res Policy 25(3):325-335

Minniti M, Bygrave W (2001) A dynamic model of entrepreneurial learning. Enterp Theory Pract 25(3):5-5

Mowery, D. C. (2004). Universities in national innovation systems. Retrieved http://www.globelicsacademy. net/pdf/DavidMowery_1.pdf 24th June 2016

McAdam M, Galbraith B, McAdam R, Humphreys P (2006) Business processes and networks in university incubators: a review and research agendas. Tech Anal Strat Manag 18(5):451-472

McAdam M, McAdam R (2008) High tech start-ups in University Science Park incubators: the relationship between the start-up's lifecycle progression and use of the incubator's resources. Technovation 28(5):277290

McAdam M, Marlow S (2008) A preliminary investigation into networking activities within the university incubator. International Journal of Entrepreneurial Behavior \& Research 14(4):219-241

McGrath, R. G., \& MacMillan, I. C. (1995). Discovery driven planning. Wharton School, Snider Entrepreneurial Center.

Oviatt BM, McDougall PP (2005) Defining international entrepreneurship and modeling the speed of internationalization. Entrepreneurship Theory and Practice 29(5):537-554

O'Kane C, Cunningham J, O'Reilly P, Mangematin V (2015) Underpinning strategic behaviours and posture of principal investigators in transition/uncertain environments. Long Range Plan 43(3):200-214

Politis D (2005) The process of entrepreneurial learning: a conceptual framework. Entrepreneurship Theory and Practice 29(4):399-424

Pirnay F, Surlemont B, Nlemvo F (2003) Toward a typology of university spin-offs. Small Bus Econ 21:355369

Rothaermel FT, Thursby M (2005) University-incubator firm knowledge flows: assessing their impact on incubator firm performance. Res Policy 34(3):305-320

Sarasvathy SD (2001) Causation and effectuation: toward a theoretical shift from economic inevitability to entrepreneurial contingency. Acad Manag Rev 26(2):243-263

Schiavone F, Meles A, Verdoliva V, Del Giudice M (2014) Does location in a science park really matter for firms' intellectual capital performance? J Intellect Cap 15(4):497-515

Stam E (2015) Entrepreneurial ecosystems and regional policy: a sympathetic critique. Eur Plan Stud 23(9): 1759-1769

Strömsten T, Waluszewski A (2012) Governance and resource interaction in networks. The role of venture capital in a biotech start-up. J Bus Res 65(2):232244

Walsh G, Cunningham JA (2016) Business failure and entrepreneurship: emergence, evolution and future research. Foundations and Trends in Entrepreneurship 12(3):163-285

Walter A, Auer M, Ritter T (2006) The impact of network capabilities and entrepreneurial orientation on university spin-off performance. J Bus Ventur 21(4):541-567

Weigel S (2011) "Medical Technology's source of innovation. Eur Plan Stud 19(1):43-61

Wright M, Lockett A, Clarysse B, Binks M (2006) University spin-out companies and venture capital. Res Policy 35(4):481-501

Ucbasaran D, Shepherd DA, Lockett A, Lyon SJ (2013) Life after business failure the process and consequences of business failure for entrepreneurs. J Manag 39(1):163-202

Van de Ven AH, Polley DE, Garud R, Venkataraman S (1999) The innovation journey. Oxford University Press, New York

Zaheer S (1995) Overcoming the liability of foreignness. Acad Manag J 38(2):341-363

Zucchella A, Siano A (2014) Internationalization and innovation as resources for SME growth in foreign markets: a focus on textile and clothing firms in the Campania region. International Studies of Management \& Organization 44:21-41 